\title{
RANGELAND CONDITION ASSESSMENT BASED ON ECONOMIC CRITERIA
}

\author{
AMIR AHMADPOUR ${ }^{1 *}$, GHOLAM Ali HESHMATI $^{1}$, RAMTIN JOULAIE $^{2}$ \\ I* Department of Rangeland Science, Gorgan University of Agricultural Science and \\ Natural Resources, Iran, * Corresponding author: phone: +989159006720, e-mail: \\ amirahmadpoor@gmail.com \\ ${ }^{2}$ Department of Agricultural Economics, Gorgan University of Agricultural Science and \\ Natural Resources, Iran
}

Received: $28^{\text {th }}$ February 2016, Accepted: $14^{\text {th }}$ May 2016

\begin{abstract}
The current concept of rangeland condition is faced with many problems that make it difficult for managers to apply. The concept is based on climax theory, which itself has been criticised by many scientists, as it also fails to reflect the real status of rangelands based on all the functions and benefits that they are able to provide. Considering the objectives of rangeland management, a new concept of rangeland condition based on ecological and economic criteria (ECEA) is suggested in this article. In this concept, rangeland condition is achieved as 'the ratio of current benefits of a rangeland to the operation costs for its ecological restoration (to the extent that the most sustainable benefits provided). Furthermore, based on this new concept an equation is developed for quantitative measurement of the rangeland condition. We believe that this new concept can solve many problems around the existing concept of rangeland condition.
\end{abstract}

Keywords: rangeland condition coefficient; ecosystem functions; ecological restoration; ecosystem benefits and costs

\section{INTRODUCTION}

Rangeland condition is defined as the current condition of a rangeland in relation to its potential status (Stoddart et al., 1955). This seemingly simple definition has many ambiguities and difficulties in operation (Schacht, 1993; Love, 1961; Jameson, 1970; Smith, 1978; Westoby et al., 1989). Most rangeland condition assessment methods that are based on this definition face many problems such as vagueness, subjectivity, inapplicability, etc. For example, in the USDA methodology (1977) favourable species composition is not explicit enough for various management objectives. Also the potential status concept at the most of the classic methods of the rangeland condition assessment are on the base of the climax theory (Clements, 1916), so many of the criticisms surrounding this theory (Friedel, 1991; Joyce, 1993; Schacht, 1993; Scarnecchia, 1995; Society for Range Management, 1995) influence these methods too. We know that vegetation changes may occur as a result of many factors, yet in the climax concept, retrogression is exclusively attributed to livestock grazing. Moreover, climax range condition was never intended for use on some regions such as 
Ahmadpour A., Heshmati G.A., Joulaie R.: Rangeland Condition Assessment Based on Economic Criteria

Mediterranean-type annual grasslands where historic inherent plant communities have been permanently replaced by annual plant communities (Schacht, 1993).

Although the concept of climax, its existence, or its comparability with the current condition are very challenging issues, the most important problem is that the ecological potential status (climax) does not always provide the maximum benefits in rangelands and this is in contrast with the rangeland management goals. For example, the climax community may be a woodland with spiny brushes, so it will not provide enough forages for livestock meanwhile it may be perfect and stable ecologically. On the other hand, some critics of the climax rangeland condition concept recommend using the soil erosion rate as the primary factor for evaluating rangeland condition. But since most rangeland soils are of an extremely fragile nature, this scheme seems not to provide completely accurate results.

Some studies at the end of the 1980s tried to make a bridge between the state and transition theory (Westoby et al., 1989) and the concept of rangeland condition (Schacht, 1993; NRC, 1994; TGUCT, 1995; Pellant et al., 2005). Among them, the methods of rangeland health, ecological site descriptions and the desired plant community are the most reputable. However, these models cannot be used in many regions due to a number of restrictions, such as a lack of sufficient data, or inability to identify desired plant community etc. On the other hand, these methods mostly emphasis on ecological aspects while economic aspects are very important in rangeland assessment. Rangeland management in definitions (Vallentine, 1971; Heady, 1975; Stoddart et al., 1975; GES, 1997; SRM, 1998) refers to a science in which we deal with the methods for the most utilization from the rangelands meanwhile maintain the ecosystem sources. Therefore, rangeland management includes an ecological objective that refers to stability of ecosystem sources and an economic objective that refers to the most exploitation from these sources (SRM, 1995). In this way, a comprehensive concept of rangeland condition must consider both ecological and economic aspects. The issue of rangeland condition is strongly related to the concepts of ecosystem functions and management goals.

Many studies that have been conducted in the context of ecosystem efficiency have presented conceptual frameworks that show a relationship between the functions and economic values of an ecosystem (de Groot, 1992; Costanza et al., 1997; Daily et al., 2000; de Groot et al., 2002; Turner et al., 2003; Ciais et al., 2005). While some other studies in definition of ecosystem function emphasized on ecological relationships (Tilman et al., 1996; Bodin \& Wiman, 2007; DSEWPC, 2011) and some of them consider the stability of an ecosystem as equal to its function (Walker, 1992; Tilman, 1999; Loreau, 2000; Loreau et al., 2001; Hooper et al., 2005; Srivastava \& Vellend, 2005). Most macro-ecosystems such as forests, rangelands, lakes, etc. are multi-functional ecosystems and often provide a complex combination of goods and services. de Groot et al. (2002) grouped ecosystem functions into four primary categories such as regulation, habitat, production, and information functions. However, it is not always possible to utilise all of these functions under a particular management regime (SCBD, 2001).

On the other hand, rangeland condition may reflect an alternative concept of ecosystem structure. For example many of rangeland condition assessment methods focus on soil, plant composition and so on. Since, understanding the relationship between the structure and functions of ecosystems seems to be essential for better conceptualisation of the rangeland condition term. Many scientists have studied the relationship between structure and function in ecosystems (e.g. Francis et al., 1979; Hobbs \& Norton, 1996; Zedler \& Callaway, 1999; Lockwood \& Samuels, 2004). Some of them have presented models for that (Bradshaw, 1984; Cortina et al., 2006), but none of them have considered this fact that the structurefunction relationship in an ecosystem is not equal for various functions. 
In an unpublished study and based on the state and transition theory, we suggested a conceptual model about the relationship between structure and multiple functions in ecosystems (SMF model). We explained that in a given ecosystem and in a particular status, various functions show different relationships with the structure and these relations may be varied in different states (Figure 1). According to this model, although the other functions show erratic behaviour, the ecological function shows a relatively direct (and no essentially linear) relationship with improvement in succession stages.

Fig. 1: Graphical ESMF Model based on state and transition theory (Ahmadpour et al., 2016)

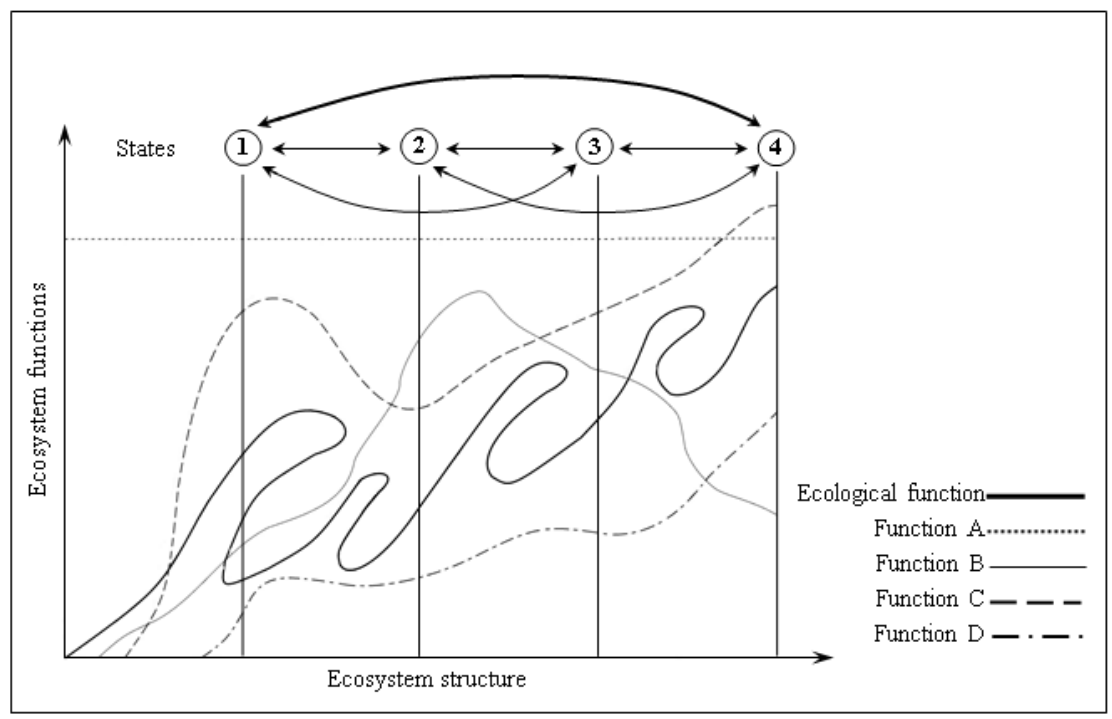

It is explicit that determination of goal function(s) is the first step in ecosystem management, so in viewpoint of management goals, we suggested two main groups for ecosystem functions: a) ecological and b) human well-being functions. We believe that ecological conservation and economic proficiency are probably the best criteria for determination of goal functions. However, since some scientists are concerned about the conflict between ecological and economic functions (Thurow, 2000; Weitzman, 2000), a new concept that can integrate these two criteria needs to be developed.

\section{A NEW CONCEPT OF RANGELAND CONDITION}

Rangelands have many benefits for people, but because of deterioration, in most instances, the benefits that they provide is much lower than their potential. Therefore, it is essential for managers to use applications that help them to restore their rangelands to the potential status. A potential status is a condition that provides the most benefits for people on the one hand and that can be sustainably utilised into the future on the other hand. What this potential conditionlstate is termed (desired plant community or climax, etc.) is not an issue but it is important that the region must be stable ecologically, for example the soil in the area must be conserved at least (Clements, 1916; TGUCT, 1995; Pellant et al., 2005). Undoubtedly, the applications which should be used for restoring the ecosystems to their potential condition 
Ahmadpour A., Heshmati G.A., Joulaie R.: Rangeland Condition Assessment Based on Economic Criteria

will need a given amount of costs in attention to the rate of destruction. So in a deteriorated rangeland we are faced with two problems: a) the benefits that have been lost b) the costs that need to be spent until the rangeland recovered its ecological potential condition.

Whatever a rangeland is more deteriorated its benefits will be more lost and in contrast its ecological restoration costs will be more increased. In these condition we recognize that the rangeland is in a poor status. Therefore, the status of a rangeland (or other ecosystem) can be determined according to the difference between its ecological restoration costs and the benefits which it can provide. Figure 2 shows a schematic model of this theory. The start point is the state in which no benefit is provided by the ecosystem and against the maximum cost is needed for its restoration, so we say it is in the worst possible condition. As the condition of the ecosystem improves, the benefits and the restoration costs will be increased and decreased respectively. The current state is the real condition that the ecosystem currently has. The difference between benefits (B) and ecological restoration costs (C) shows the current state.

Fig. 2: Schematic model of rangeland condition determination based on its benefits (B) and the costs that are needed for its ecological restoration $(C)$

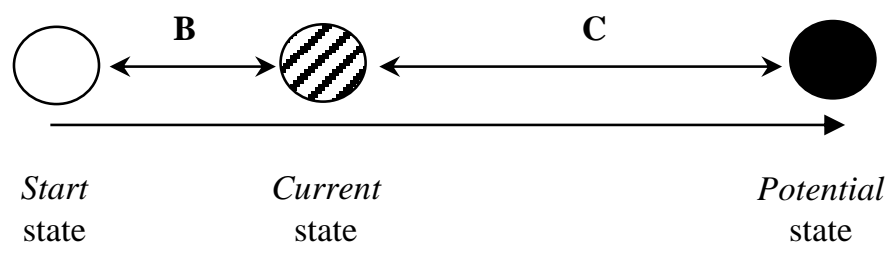

The current state is fair when the costs and benefits are equal or the difference between them is zero. The potential state is the best condition, at which the maximum benefits can be gained from the ecosystem and no cost is needed for its ecological restoration. However, the start and potential states are just theoretical states and they may never be seen in reality. Nevertheless, the mere difference between costs and benefits cannot provide a standard index for rangeland condition. In fact, there needs to be a scale that can judge several conditions. Accordingly, we need a concept that can gather all of these characteristics.

In this paper, a new procedure of rangeland condition is suggested based on Economic Criteria and in attention to Ecological Aspects (ECEA), which can be useful for revealing the real situation of rangelands in any regions. In this concept, rangeland condition is defined as the ratio of current benefits of a rangeland to operation costs for its ecological restoration. The ecological restoration must be implemented to the level that the most benefits and the maximum conservation are provided by the ecosystem. The current benefits at this definition 
mean all of good and services such as animal production, apiculture, medical, industrial and recreational uses, etc. that provide a given income for rangeland utilizers during the current year. It must be noticed that the benefits which can be utilized from a given rangeland may be different with benefits utilized from another ones. The utilization options for each rangeland are mostly selected in attention to its suitability. Also restoration costs is specific for each rangeland in attention to their properties.

Evaluation of rangeland condition for an annual period is usual for all of the other methods, for example vegetation cover index, that is used in all of methods, is specific for that year but it may changes during next years. However, condition changes during time is itself a character and it is named as rangeland trend. So we should suggest a method that its results can be comparable during the time. Since, a quantitative method for evaluating rangeland condition was also developed, which works based on a mathematical equation. The rangeland condition coefficient (RCC) in this method is estimated as follows:

$$
R=B-C / B+C
$$

$B$ is sum of the financial value of the benefits that are currently provided by the rangeland, and $C$ is the costs that must be paid until the rangeland is restored ecologically. The costs must be estimated for the level of restoration that would achieve the most rational benefits. The value of RCC can vary between -1 (the worst state) and +1 (the best state) and managers themselves can judge the condition of their rangeland. The worst state occurs when no benefits are achieved and heavy restoration plans are needed until the rangeland recovered its potential status. Conversely, the best state occurs when maximum benefits are achieved without any restoration operations. Although this method uses economic criteria for assessment but the rate of discounting benefits and costs can not affect it. In fact, discount rate is a coefficient that effects on benefits and costs to the same extent. At the suggested equation, $B$ and $C$ were repeated at both numerator and denominator so the equation will not be affected by any coefficients.

\section{Advantages of the new concept}

Some advantages of the application of the ECEA procedure include:

- It is not based on climax or other imprecise ecological theories, which enables it to remain immune to the criticisms directed towards these theories.

- In this procedure, although the elements that are used for measuring the RCC are just economic criteria but when we talk about costs, it refers to the costs needed for ecological development of rangelands. In fact the ecological criteria is tacitly considered on the approach.

- It can be used in all regions and provides rational results, whereas some traditional concessive methods do not present accurate results in some regions. For example, the four-factor method that was developed by the USDA (1987) classifies arid and semi-arid rangelands at a lower level than their real condition (Moghaddam, 2001).

- It is goal-based and considers all functions of rangelands, for example grazing, apiculture, eco-tourism, etc. In fact, every function in rangeland has an economy that must be noticed in viewpoint of management goals, so we should evaluate them and select the best functions for utilization.

- All ecological relationships and resources in the region, such as climate, vegetation, water, soil, biodiversity, etc. are to be considered in the evaluations. In fact, when we are going to evaluate and select the best functions for utilization and to select the best implementations for restoration we firstly must study all of effecting elements on the region. 
Ahmadpour A., Heshmati G.A., Joulaie R.: Rangeland Condition Assessment Based on Economic Criteria

- Rangeland condition is estimated as a coefficient instead of a solid classification. In concessive methods (USDA, 1977, 1987) for the determination of rangeland condition we usually give scores to some factors and then by the sum of these scores we classify the rangeland condition in the related category. In some instances, two rangelands with close scores may be located in two different classes, while two rangelands with very far scores may be categorized in a same class. For example a rangeland with the score of 49 may be classified at the poor condition class while a rangeland with the score of 50 is categorized at the fair class (although the difference between 49 and 50 is not considerable) and yet another rangeland with score of 69 is also categorized at the fair class (although the difference between 50 and 69 is much more).

- Satisfies the aim of public and private rangeland managers to determine the condition of their rangelands. Managers want to know about the public rangelands because they want to monitor the effects of utilization on the rangelands. As was mentioned above, this procedure can be applied and compared in continuous years. Public rangeland managers want to know about the condition of their ecosystems because, in addition to above reason, they want to know if their rangelands can provide more benefits for them or not. The presented procedure consider this aim too, because as be mentioned this procedure consider all of functions that can provide benefits for utilizers.

- It is explicit for application because managers can adopted it with their goals. Moreover, economic criteria are more objective and measurable, leading assessors to be more accurate.

\section{Challenges}

One of the most important challenges for the application of this procedure is how the benefits and costs should be assessed. There are already various methods for such economic evaluations in the context of natural resources (Valentine, 1971; Macleod \& Johnston, 1990; Turner et al., 1999; Tietenberg, 2006; Harris, 2006; Hacket, 2006; Hanley, 2007; Lipton, 1995; Workman, 1984; Workman et al., 1991; Costanza et al., 1997; Neumann \& Hirsch, 2000; Gram, 2001; Mattson \& Li, 1993; Mankiw, 2009). Although many of these methods cannot present completely accurate results, they are used in a wide and effective manner in the economic justification of utilisation plans. In addition, it must be noted that all of the methods that are already used for the study of natural systems are always faced with a percentage of errors, and the RCC method is no exception in this context.

During the usage of RCC, all functions that have markets are valued, from which one (or more) function(s) that has/have the most benefits is/are determined as the goal function(s). In fact, managers should decide about utilization priorities in their rangeland and based on this decision select the functions that should be considered in assessment of rangeland condition. It is clear that in terms of the multiple uses of a rangeland, among the various functions provided by a rangeland those which are not in conflict with each other can be included in the calculations, where $B$ is their sum. Although many of the ecosystem functions do not have markets and it is necessary to use non-market valuation techniques to value them (Elsasser, 1999; Gunawardena et al., 1999; Chomitz \& Kumari, 1996), the ECEA concept only considers the functions that potentially have a market. In fact, since the ECEA concept is focused on the economic utilisation of rangelands and their ecological conservation, the functions that people would like to pay for are assessed. It is explicit that ecological functions are considered by including restoration costs in the RCC equation.

Another issue that could challenge the ECEA concept is the changing value of economic benefits as well as costs of restoration in the future. The condition of a rangeland is really a snapshot of the management proficiency implemented on it, but the measurement of this 
condition must be able to show how management applications affect the rangeland over time. The ECEA concept is based on the fact that if rangeland condition is worse, the costs for rangeland restoration (to a given level) are greater, and so RCC is lower. If the condition of the rangeland is will be better in the future, in addition to reducing restoration costs, the benefits and thus RCC will increase. This positive or negative trend will show how effective the management of the rangeland is. It must be noticed, although economic elements are changing during the time, but the nature of RCC is in a way that is not affected by external changes. For example, a factor that might affect financial assessment is the change in the value of benefits and costs over time due to economic inflation. In this regard, we can say that as RCC is a ratio in which costs and benefits are involved in both the numerator and denominator, and as the inflation coefficient will affect them at the same rate, mathematically the inflation coefficient cannot affect RCC. In fact, each external factor that has an effect on restoration costs will affect the value of benefits too. Therefore, external factors that are segregated from the change in rangeland condition will not have an effect on RCC.

\section{CASe STUdy}

In order to test this method, we analysed data from 23 plant communities in various rangelands in the north-east of Iran. Some characteristics of the plant communities are presented in Table 1. In the study, livestock products, apiculture, and by-products such as edible, medicinal, and industrial plants were investigated as the most important functions (benefits). Nevertheless, very important benefits, such as recreational function, were ignored in this study because of financial restrictions. For the study area we used a randomly systematic sampling method with a density of 10 plots $\left(1 \mathrm{~m}^{2}\right)$ in hectare. In each plot firstly vegetation cover and plant composition were measured and so measurements was done through cutting and weighing method to estimate the forage production. The grazing capacity for each community was estimated and the proceeds from the sale of the according number of animals was calculated based on market prices. Achieved incomes from apiculture and by-products were estimated through questionnaires and interviews with at least 7 expert people in the respective areas.

Various field and official studies were also conducted to determine the required restoration projects and to estimate their costs. Most of information that was needed to estimate the restoration costs was extracted from the data provided by some previous studies (IFRO, 2013). Finally, according to these benefits and costs RCC was calculated for each area (community) based on the above suggested equation. Figure 3 shows the results of the study.

These results were compared with those achieved using the traditional USDA concessive method (Moghaddam, 2001). The comparisons showed that in many cases there are distinct differences between the results of the two methods (Table 1). An example is the mountainous areas of the Goloul va Sarani protected area, which are abundantly dominated by Astragalus gossypinus and Onobrychis cornuta. These plants are not suitable for grazing, but are the best species for apiculture and can also prevent soil erosion very well. Although these rangelands were categorised in the fair class using the concessive method, they can provide an annual income of more than $5000 \$ /$ ha without any restoration plans being implemented in the area (other utilisations such as recreational functions could probably provide more income than this). Notice that the utilisation based on apiculture can improve the condition of these rangelands over time. 
Ahmadpour A., Heshmati G.A., Joulaie R.: Rangeland Condition Assessment Based on Economic Criteria

Fig. 3: Benefits, restoration costs and rangeland condition coefficients in each site using the EEC method

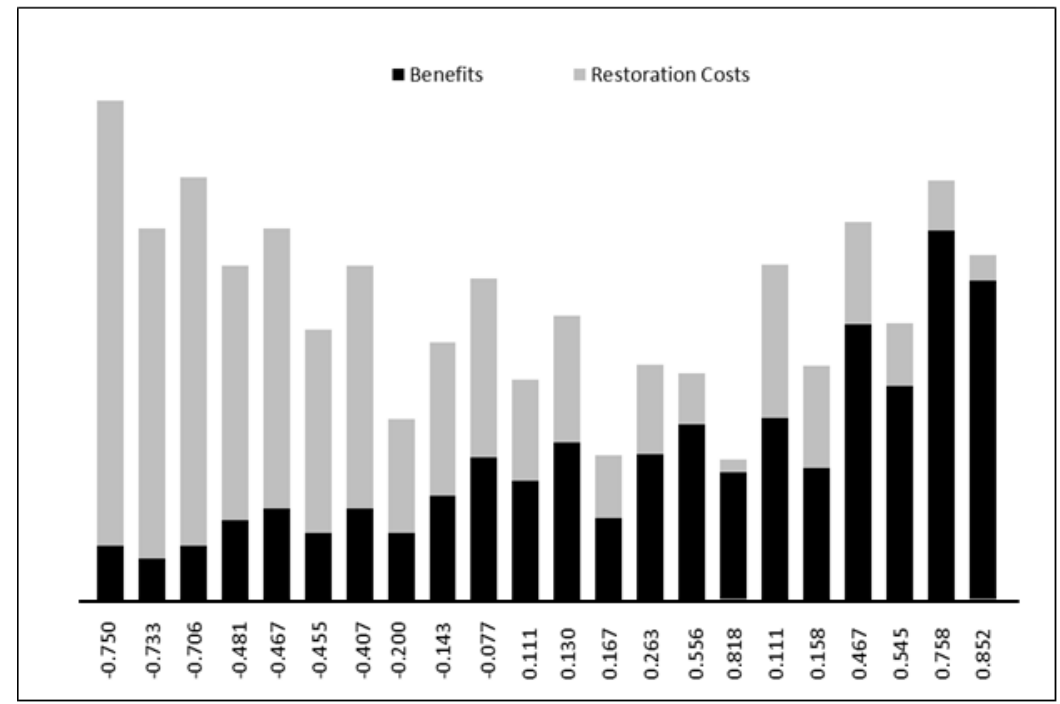

Our studies showed that the multi-purpose usage of rangelands mostly provides more advantages (Figure 4), while in traditional methods of rangeland condition assessment only one function is considered. As can be seen in Table 1, fair rangelands (determined using traditional methods) in some instances may provide more incomes than good condition rangelands.

Fig. 4: Increased benefits as a result of increased multiple use of ecosystem functions

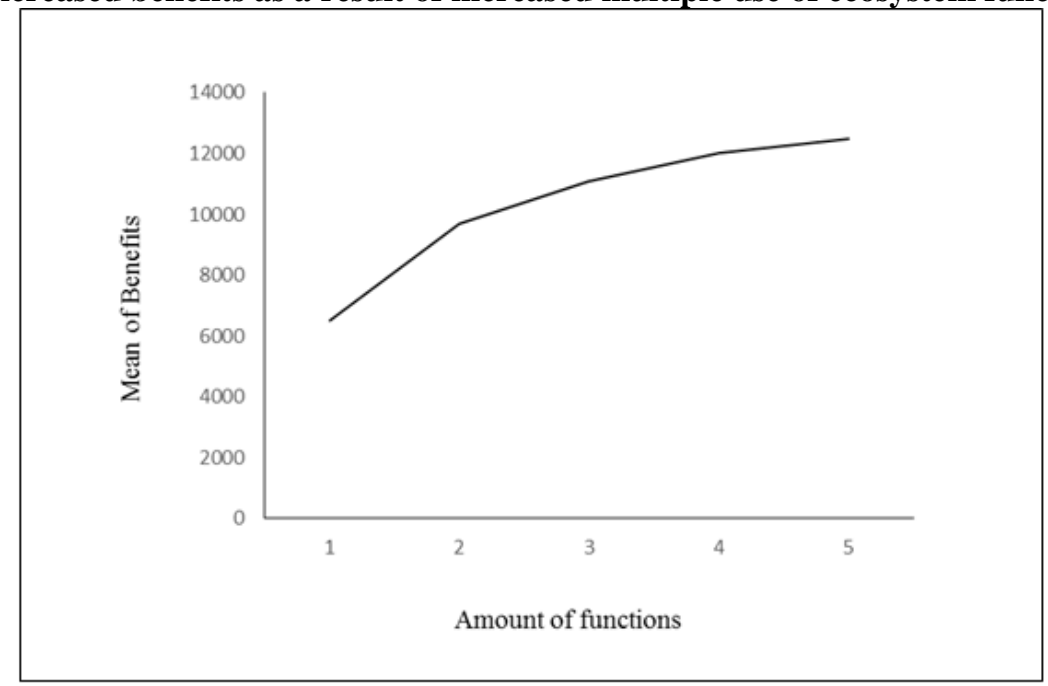


Table 1. Results of rangeland condition estimation using U.S. Department of Agriculture (USDA) and Ecological and Economic Criteria (EEC) methods in various locations

\begin{tabular}{|c|c|c|c|c|c|c|c|c|c|c|c|c|}
\hline \multirow{2}{*}{ Location } & \multirow{2}{*}{$\begin{array}{l}\text { Extent } \\
\text { (1000ha) }\end{array}$} & \multicolumn{4}{|c|}{ Benefits per year $(1000 \$)$} & \multicolumn{4}{|c|}{ Restoration costs $(1000 \$)$} & \multicolumn{2}{|c|}{$\begin{array}{c}\text { Rangeland } \\
\text { condition }\end{array}$} & \multirow{2}{*}{-Compare } \\
\hline & & $\begin{array}{c}\text { Livestock } \\
\text { products }\end{array}$ & Apiculture & Byproduct & Total & $\begin{array}{l}\text { Managing } \\
\text { operations }\end{array}$ & $\begin{array}{l}\text { Ecological } \\
\text { operations }\end{array}$ & $\begin{array}{c}\text { Mechanical } \\
\text { operations }\end{array}$ & Total & $\begin{array}{l}\text { USDA } \\
\text { method }\end{array}$ & $\begin{array}{c}\text { EEC } \\
\text { method }\end{array}$ & \\
\hline $4111874 \mathrm{~N}-699842 \mathrm{E}$ & 1.5 & 18 & 5 & 2 & 25 & 2 & 0 & 0 & 2 & Excellent & 0.852 & - \\
\hline $4108074 \mathrm{~N}-709253 \mathrm{E}$ & 1 & 20 & 6 & 3 & 29 & 2 & 2 & 0 & 4 & Excellent & 0.758 & - \\
\hline $4114963 \mathrm{~N}-711638 \mathrm{E}$ & 1.7 & 13 & 3 & 1 & 17 & 2 & 3 & 0 & 5 & Excellent & 0.545 & - \\
\hline $4110918 \mathrm{~N}-701466 \mathrm{E}$ & 3.6 & 12 & 5 & 5 & 22 & 3 & 5 & 0 & 8 & good & 0.467 & - \\
\hline $4094618 \mathrm{~N}-674929 \mathrm{E}$ & 3.2 & 10 & 0 & 1 & 11 & 2 & 6 & 0 & 8 & good & 0.158 & - \\
\hline $4095525 \mathrm{~N}-677505 \mathrm{E}$ & 1.3 & 10 & 3 & 2 & 15 & 3 & 9 & 0 & 12 & good & 0.111 & $\uparrow$ \\
\hline $4113840 \mathrm{~N}-699332 \mathrm{E}$ & 2.2 & 3 & 4 & 3 & 10 & 1 & 0 & 0 & 1 & Fair & 0.818 & $\downarrow$ \\
\hline $4109614 \mathrm{~N}-700150 \mathrm{E}$ & 1 & 4 & 8 & 2 & 14 & 2 & 2 & 0 & 4 & Fair & 0.556 & $\downarrow$ \\
\hline $4090456 \mathrm{~N}-677187 \mathrm{E}$ & 4.4 & 7 & 2 & 3 & 12 & 2 & 3 & 2 & 7 & Fair & 0.263 & $\downarrow$ \\
\hline $4092080 \mathrm{~N}-676879 \mathrm{E}$ & 3.9 & 4 & 1 & 2 & 7 & 1 & 2 & 2 & 5 & Fair & 0.167 & - \\
\hline $4113322 \mathrm{~N}-709304 \mathrm{E}$ & 2.7 & 8 & 4 & 1 & 13 & 1 & 3 & 6 & 10 & Fair & 0.130 & - \\
\hline $4115778 \mathrm{~N}-703161 \mathrm{E}$ & 3.1 & 4 & 3 & 3 & 10 & 2 & 2 & 4 & 8 & Fair & 0.111 & - \\
\hline $4094789 \mathrm{~N}-674786 \mathrm{E}$ & 1.6 & 8 & 3 & 1 & 12 & 2 & 3 & 9 & 14 & Fair & -0.077 & $\uparrow$ \\
\hline $4113537 \mathrm{~N}-702663 \mathrm{E}$ & 3.5 & 5 & 2 & 2 & 9 & 1 & 2 & 9 & 12 & Fair & -0.143 & $\uparrow$ \\
\hline $4110585 \mathrm{~N}-710258 \mathrm{E}$ & 1.8 & 5 & 1 & 0 & 6 & 1 & 2 & 6 & 9 & Fair & -0.200 & $\uparrow$ \\
\hline $4111759 \mathrm{~N}-702438 \mathrm{E}$ & 3.7 & 4 & 3 & 1 & 8 & 2 & 4 & 13 & 19 & Poor & -0.407 & - \\
\hline $4094441 \mathrm{~N}-677120 \mathrm{E}$ & 2.9 & 3 & 1 & 2 & 6 & 2 & 3 & 11 & 16 & Poor & -0.455 & - \\
\hline $4109890 \mathrm{~N}-708994 \mathrm{E}$ & 4.2 & 6 & 0 & 2 & 8 & 2 & 7 & 13 & 22 & Poor & -0.467 & - \\
\hline $4110310 \mathrm{~N}-698224 \mathrm{E}$ & 2.6 & 2 & 4 & 1 & 7 & 3 & 3 & 14 & 20 & Poor & -0.481 & - \\
\hline $4085223 \mathrm{~N}-670364 \mathrm{E}$ & 1 & 4 & 0 & 1 & 5 & 4 & 5 & 20 & 29 & Poor & -0.706 & - \\
\hline $4086384 \mathrm{~N}-670151 \mathrm{E}$ & 1.6 & 3 & 0 & 1 & 4 & 2 & 6 & 18 & 26 & Poor & -0.733 & - \\
\hline $4086920 \mathrm{~N}-670727 \mathrm{E}$ & 1.3 & 3 & 0 & 2 & 5 & 4 & 6 & 25 & 35 & Poor & -0.750 & - \\
\hline
\end{tabular}

* The raised arrows $(\uparrow)$ showed that the EEC rangeland condition coefficient is low, but it was categorized in a higher class using USDA method and vice versa. 


\section{DISCUSSION}

Assessment of rangeland condition is one of the most important issues in determination of management strategies. Smith (1979) believes that rangeland condition is the most important concept in managing rangelands. However, the current concept of rangeland condition is so obscure that it is not applicable in many cases. These definitions are mostly based on the concept of climax, which has been rejected by many scientists. Therefore, it is essential to find a new concept that can provide a better understanding of rangeland condition and also reflect the real status of plant communities with sufficient clarity. Rangelands are ecosystems with many functions, and therefore a comprehensive definition of rangeland condition is needed to consider all of them.

Ecological conservation and economy are two important subjects in the rangeland management, so any methods that are developed to evaluate rangeland condition must involve both of these aspects to be in agreement with rangeland management goals. Rangeland management is defined as 'the science and art of planning and directing range use so as to obtain the maximum livestock production consistent with range resources' (Stoddart et al., 1955; Vallentine, 1971). We think that the presented procedure of rangeland condition based on ECEA can help us to arrive at this objectives.

\section{SUGGESTIONS}

It seems that change to the concept of rangeland condition is unavoidable due to the many problems that the current concept presents. This study could be the first step towards a change. The authors suggest the RCC method to be examined by more studies in various regions. Scientists should consider it and seek to reveal any defects or even suggest better equations. The efficiency of the proposed method over previous methods must be investigated by more studies.

\section{ACKNOWLEDGEMENTS}

The authors are grateful to G. Ghorbani and F. Ghadiri for helping with the office works. We thank many people for helping with the field studies, especially R. Yari and H. Shakib. This study was financial supported by Gorgan University of Agricultural Sciences and Natural Resources.

\section{REFERENCES}

Ahmadpour, A., Heshmati, G.A., (2016). Struvture, Functions and Their Relations in Ecosystems, a viewpoint. Unpublished study.

Bodin, P., Wiman, B.L.B., (2007). The usefulness of stability concepts in forest management when coping with increasing climate uncertainties. Forest Ecology and Management 242, 541-552.

Bradshaw, A.D., (1984). Ecological principles and land reclamation practice. Landscape Planning, 11, 35-48.

Chomitz, K., Kumari, K., (1996). The Domestic Benefits of Tropical Forests: a Critical Review,Working paper 96- 19, CSERGE, University of East Anglia and University 
College London.

Ciais, P.H., Reichstein, M., Viovy, N., Granier, A., Oge'e, J., Allard, V., Aubinet, M., Buchmann, N., Bernhofer, Chr., Carrara, A., Chevallier, F., De Noblet, N., Friend, A.D., Friedlingstein, P., Grünwald, T., Heinesch, B., Keronen, P., Knohl, A., Krinner, G., Loustau, D., Manca, G., Matteucci, G., Miglietta, F., Ourcival, J.M., Papale, D., Pilegaard, K., Rambal, S., Seufert, G., Soussana, J.F., Sanz, M.J., Schulze, E.D., Vesala, T., Valentini, R., (2005). Europe-wide reduction in primary productivity caused by the heat and drought in 2003. Nature, 437, 529-533.

Clements, F.E., (1916). Plant succession: an analysis of the development of vegetation. Carnegie Inst., Washington Pub., 242, 1-512.

Cortina, J., Maestre, F.T., Vallejo, R., Baeza, M.J., Valdecantos, A.L., Pe'rez-Devesa, M., (2006). Ecosystem structure, function, and restorationsuccess: Are they related? Journal for Nature Conservation, 14, 152-160.

Costanza, R, D'Arge, R., de Groot, R., Farber, S., Grasso, M., Hannon, B., Limburg, K., Naeem, S., O'Neill, S., Paruelo, J., Raskin, R., Sutton P., van den Belt, M., (1997). The value of the world's ecosystem services and natural capital, Nature, 387, 253-260.

Costanza, R., d'Arge, R., de Groot, R.S., Farber, S., Grasso, M., Hannon, B., Limburg, K., Naeem, S., O'Neill, R.V., Paruelo, J., Raskin, R.G., Sutton, P., van den Belt, M., (1997). The value of the world's ecosystem services and natural capital. Nature, 387, 253-60.

Daily, G.C., Soderquist, T., Aniyar, S., Arrow, K., Dasgupta, P., Ehrlich, P.R., Folke, C., Jannson, A., Jansson, B.O., Kautsky, N., Levin, S., Lubchenco, J., Maler, K.G., David, S., Starrett, D., Tilman, D., Walker, B., (2000). The value of nature and the nature of value. Science, 289, 395-396.

de Groot, R.S., (1992). Functions of Nature: Evaluation of Nature in Environmental Planning, Management and Decision-Making. Wolters Noordhoff BV, Groningen, The Netherlands.

de Groot, R.S., Wilson, M., Boumans, R., (2002). A typology for the description, classification and valuation of ecosystem functions, goods and services. Economics, 41, 393-408.

DSEWPC, Department of Sustainability, Environment, Water, Population and Communities, (2011). ACRIS Landscape Function Update 2006-2010: Updated Information to That Provided in Rangelands 2008- Taking the Pulse. Commonwealth of Australia. 37p.

Elsasser, P., (1999). Recreational benefits of forests in Germany, in C.Roper and A.Park (eds), The Living Forest: the Non-market Benefits of Forestry (pp. 175-188), London: The Stationery Office.

Francis, G.R., Magnuson, J.J., Regier, H.A., Talhelm, D.R., (1979). Rehabilitating Great Lakes Ecosystems. Great Lakes Fishery Commision. Technical Report 37, Ann Arbor, MI., pp. 1-107.

Friedel, M. H., (1991). Range condition assessment and the concept of threshold -a viewpoint. J. Range Manage. 44:422-426.

GES, Glossary of Environment Statistics, (1997). Studies in Methods, Series F, No. 67, United Nations, New York.

Gram, S., (2001). Economic valuation of special forest products: an assessment of methodological shortcomings, Ecological Economics, 36, 109-117.

Gunawardena, U., Edwards-Jones, G and McGregor, M., (1999). A contingent valuation approach for a tropical rainforest: a case study of Sinharaja rainforest reserve in Sri Lanka, In 
Ahmadpour A., Heshmati G.A., Joulaie R.: Rangeland Condition Assessment Based on Economic Criteria

Roper S and Park, A (eds), The Living Forest: the Non-Market Benefits of Forestry (pp. 275-284),London: The Stationery Office.

Hacket, S., C., (2006). Environmentas and Natural Resources Economics. London: Armonk, New York.

Hanley, N., Shogren, J., White, B., (2007). Environmental Economics in Theory and Practice, Palgrave, London.

Harris, J., (2006). Environmental and Natural Resource Economics: A Contemporary Approach. Houghton Mifflin Company.

Hobbs, R.J., Norton, D.A., (1996). Towards a conceptual framework for restoration ecology. Restor. Ecol., 4(2), 93-110.

Hooper, D.U., Chapin III, F.S., Hector, A., Inchausti, P., Lavorel, S., Lawton, J.H., Lodge, D.M., Loreau, M., Naeem, S., Schmid, B., Seta“la“, H., Symstad, A.J., Vandermeer, J., Wardle, D.A., (2005). Effects of biodiversity on ecosystem functioning: a consensus of current knowledge. Ecol. Monogr., 75, 3-35.

IFRO, Iranian Forest and Rangelands Organization, (2013). Reports of rangelands and watersheds comprehensive plans in Khorasan Province, Mashhad. In Persian.

Jameson, D. A., (1970). Land management policy and development of ecological concepts. J. Range Manage. 23:316-321.

Joyce, L. A., (1993). The life cycle of the range condition concept. Journal of Range Management, 46:132-138.

Lipton, D.W., K. Wellman, I.C. Sheifer, R.F. Weiher, (1995). Economic valuation of natural resources: a handbook for coastal resource policymakers. U.S. Dept. of Commerce, National Oceanic and Atmospheric Administration, Coastal Ocean Office, Silver Springs, MD.

Lockwood, J.L., Samuels, C.L., (2004). Assembly Models and the Practice of Restoration. In V.M., Temperton, R.J., Hobbs, T., Nuttle, S., Halle, (Eds.), Assembly Rules and Restoration Ecology (pp. 34-54). Washington: Island Press.

Loreau, M., (2000). Biodiversity and ecosystem functioning: recent theoretical advances. Oikos, 91, 3-17.

Loreau, M., Naeem, S., Inchausti, P., Bengtsson, J., Grime, J.P., Hector, A., Hooper, D.U., Huston, M.A., Raffaelli, D., Schmid, B., Tilman, D.,Wardle, D.A., (2001). Biodiversity and ecosystem functioning: current knowledge and future challenges. Science, 294, 804-808.

Love, R.M., (1961). The range-natural plant communities or modified ecosystems? J. Brit. Grassl. Soc., 16:89-99.

Macleod, N.D. and Johnston, B.G., (1990). An economic framework for the evaluation of rangeland restoration projects. The Australian Rangeland Journal, 12(1) 40 - 53.

Mankiw, N.G. (2012). Principles of Microeconomics, South- Western Cengage Learning, $6^{\text {th }} \mathrm{Ed}$.

Mattson, L and Li, C., (1993). The non-timber value of Northern Swedish forests, Scandinavian Journal of Forest Research, 8, 426-434.

Moghaddan, M.R., (2001). Range and Range Management. 2nd ed., University of Tehran. In Persian. 
Neumann, R and Hirsch, E., (2000). Commercialisation of Non-Timber Forest Products: Review and Analysis of Research, Bogor, Indonesia: Center for International Forestry Research.

NRC, National Research Council, (1994). Rangeland Health. New Methods to Classify, Inventory, and Monitor Rangelands. National Academy Press, Washington, D.C.

Pellant, M., P. Shaver, D.A. Pyke, and J.E. Herrick, (2005). Interpreting indicators of rangeland health, version 4. Technical Reference 1734-6. U.S. Department of the Interior, Bureau of Land Management, National Science and Technology Center, Denver, CO. BLM/WO/ST-00/001+1734/REV05. 122 p.

Schacht, W. H., (1993). A new approach for range condition assessment is needed. Rangelands, 15, 245-247.

Scarnecchia, D. L., (1995). Viewpoint: the rangeland condition concept and range sciences search for identity: a system viewpoint. Journal of Range Management, 48:181-186.

SCBD, Secretariat of the Convention on Biological Diversity, (2001). The Value of Forest Ecosystems. CBD Technical Series no. 4. Montreal, SCBD, 67p.

Schacht, W. H., (1993). A new approach for range condition assessment is needed. Rangelands, 15:245-247.

Smith, E.L., (1978). A critical evaluation of the range condition concept. In: D.N. Hyder (Ed). Proc. First Int. Rangeland Congr. Soc. Range Manage (pp 266-267). Denver, Colo.

Smith, E.L., (1979). Evaluation of the range condition concept. Rangelands. 1, 52-54.

Srivastava, D.S., Vellend, M., (2005). Biodiversity-Ecosystem function research: Is it relevant to conservation. Annu. Rev. Evol. Syst., 36, 267-294.

SRM, Society for Range Management, Task Group in Concepts and Terminology, (1995). New concepts for assessment of rangeland condition. Journal of Range Management 48:271-282.

Stoddart, L.A., Smith, A.D., Box, T.W., (1955). Range Management. 2nd ed., Mc Graw Hill Book Company. New York.

TGUCT, Task Group for Unity in Concepts and Terminology, (1995). New concepts for assessment of rangeland condition. J. Range Manage., 48, 271-282.

Thurow, T.L., (2000). Hydrologic effects on rangeland degradation and restoration processes. In:Rangeland Desertification (eds. Arnalds, O. and Arc her, S.). Kluwer Academic Publishers (pp. 53-66), Dordrecht.

Tietenberg, T., (2006). Environmental and natural resource economics. Boston Pearson/Addison Wesley.

Tilman, D., (1999). The ecological consequences of changes in biodiversity: a search for general principles. Ecology, 80, 1455-1474.

Tilman, D., Wedin, D., Knops, J. (1996). Productivity and sustainability inuenced by bio-diversity in grassland ecosystems. Nature, 379, 718-720.

Turner, K., R., Pearce, D., Baterman, I., (1999). Environmental economics, Baltimore: The Johns Hopkins University Press, 1999.

Turner, R.K., Paavola, J., Cooper, P., Farber, S., Jessamy, V., Georgiou, S., (2003). Valuing nature: lessons learned and future research directions. Ecological Economics, 46, 493-510.

USDA, Soil Conservation Service, (1977). Grazing guide for potential climax forest sites and condition classes, Montana foothills and mountains area. Bozeman, Mont. 
Ahmadpour A., Heshmati G.A., Joulaie R.: Rangeland Condition Assessment Based on Economic Criteria

USDA, U.S. Forest Service, (1987). Ecosystem classification handbook. Chapter four-Ecodata sampling method. FSH 12/87 R-1. Missoula, Mont.

Valentine, J.F., (1971). Range development and improvements. 2nd ed., UT: Brigham Young University Press; 545 p. Provo, Utah.

Walker, B.H., (1992). Biodiversity and ecological redundancy. Conserv. Biol., 6, 18-23.

Weitzman, M.L., (2000). Economic profitability versus ecological entropy. Quarterly Journal of Economics, 115(1): 237-263.

Westoby, M., Walker, B., Noy-Meir, I., (1989). Opportunistic management for rangelands not at equilibrium. Journal of Range Management, 42(4), 266-274.

Workman, John P., (1984). Criteria for investment feasibility and selection. In: Developing Strategies for Rangeland Management (p. 1475-1507), National Research Council/National Academy of Science. Westview Press, Boulder, Colo.

Workman, John P. and John A. Tanaka, (1991). Economic feasibility and management considerations in range revegetation. Journal of Range Management, 44(6):566-573.

Zedler, J.B., Callaway, J.C., (1999). Tracking wetland restoration: Do mitigation sites follow desired trajectories? Restoration Ecology, 7, 69-73. 